\title{
The Effectiveness of Using Emodemo Methods on Knowledge of Pregnant Women's Nutritional Needs
}

\author{
Yasi Anggasari*, Ika Mardiyanti \\ Faculty of Nursing and Midwifery, Nahdlatul Ulama University Surabaya, Indonesia \\ *yasi@unusa.ac.id
}

\begin{abstract}
KEK in pregnant women can increase the risk of premature birth, low birth weight, maternal and infant mortality. Lack of knowledge about nutritional needs is one of the causes of KEK in pregnant women. GAIN is launching a new technique in nutrition education, namely emodemo. The purpose of this study was to determine the effectiveness of using the emodemo method on knowledge of the nutritional needs of pregnant women. Research Preexperimental design with one group pretest posttest desaign design. The population of all pregnant women at PMB Nanik Sidoarjo was 30 samples by means of purposive sampling carried out for 3 months, namely June-August 2020. Data collection was in the form of a questionnaire. Statistical test using the Wilcoxon Sign Rank Test. The statistical test results obtained a significance value of 0.000 ( $p$ value $<0.005$ ) which means that there is an effect of using the emodemo method on knowledge of the nutritional needs of pregnant women. Mother's knowledge about nutritional needs increased after receiving health education through Emo demo.
\end{abstract}

Keywords: Emodemo, Knowledge, Pregnant Women 


\section{STRADA Jurnal Ilmiah Kesehatan}

DOI: $10.30994 /$ sjik.v9i2.506

ISSN: 2252-3847 (print); 2614-350X (online)

Vol.9 No.2 November 2020 Page. 1605-1610

\section{BACKGROUND}

Maternal health is one of the main keys for the health of future generations, while children's health is an asset of the State in the future (Hogan et al, 2010). However, maternal and child mortality remains a major problem for the health system in Indonesia. Anemia in pregnancy is one of the causes of high MMR in Indonesia due to Iron Deficiency Anemia (ADB) and Chronic Energy Deficiency (KEK). Anemia and KEK in pregnant women can increase the risk of premature birth, low birth weight babies (LBW), stunting (short children), and maternal and infant mortality. This occurs due to a lack of optimal nutritional intake since before pregnancy and during pregnancy.

The prevalence of KEK in pregnant women in Indonesia based on the results of Riskesdas in 2018 was $17.3 \%$, while the incidence of anemia among pregnant women in Indonesia increased from $37.1 \%$ in 2013 to $48.9 \%$ in 2018 pregnant women who experienced anemia. Preliminary data in PMB Sidoarjo obtained data from 10 trimester pregnant women, there are 4 people (40\%) who have KEK and there are 2 people $(20 \%)$ women experiencing anemia out of 10 pregnant women only 3 people who know the nutritional needs of pregnant women

Lack of knowledge of mothers about their needs nutrition is a factor that can cause KEK in pregnant women. Arifin's research results, 2016, there is a relationship between the knowledge of pregnant women about nutritional needs with the nutritional status of pregnant women, if the knowledge of pregnant women about good nutritional needs will certainly be aware of the impact of not fulfilling nutrition so that mothers will try to maintain their health which will affect their nutritional status.

Interventions that can be carried out to solve KEK problems related to the knowledge of pregnant women are by providing nutrition education so that it can help individuals and communities to practice healthy living behaviors, especially those related to food choices. GAIN (Global Alliance for Improved Nutrition) launched a new technique in nutrition education, namely emodemo (emotional demonstration). Emo demo is a technique that can increase behavior change by way of demonstrations that are fun and emotional so that they are easy to remember and have a very strong impact.

\section{METHODS}

This research is a type ofresearch pre-experimental design with a one group pretest posttest desaign design. Observation was conducted 2 times, namely before the experiment (pre-test) and after the experiment (post test), which aims to determine the level of mother's knowledge. independent variable of health education using emodemo method, while the dependent variable is the mother's knowledge about the nutritional needs of pregnant women. The population of all pregnant women in PMB Nanik Sidoarjo by purposive sampling.

The research was conducted for 3 months, namely June-August 2020 at PMB Nanik Sidoarjo. Data collection in the form of a questionnaire. After the data was collected, the data were analyzed using statistical tests, namely the Wilcoxon Sign Rank Test. 


\section{STRADA Jurnal Ilmiah Kesehatan}

DOI: $10.30994 /$ sjik.v9i2.506

ISSN: 2252-3847 (print); 2614-350X (online)

Vol.9 No.2 November 2020 Page. 1605-1610

RESULT

Table 1. Frequency Distribution of Respondents based on Maternal Age at PMB Nanik Sidoarjo in 2020

\begin{tabular}{lcc}
\hline \multicolumn{1}{c}{ Maternal Age } & Frequency & Percentage $(\%)$ \\
\hline$<20$ years & 10 & 33.3 \\
$20-35$ years old & 20 & 66.7 \\
$>35$ years old & 0 & 0 \\
\hline Total & 30 & 100 \\
\hline
\end{tabular}

Source: primary data 2020

Table 1 shows the results of most (66.7\%) respondents aged 20- 35 years.

Table 2.Frequency Distribution of Respondents Based on Mother Education at PMB Nanik Sidoarjo in 2020

\begin{tabular}{lcc}
\hline \multicolumn{1}{c}{ Mother Education } & Frequency & Percentage (\%) \\
\hline SMP & 2 & 6.7 \\
SMA / SMK & 22 & 73.3 \\
PT & 6 & 20 \\
\hline Total & 30 & 100 \\
\hline
\end{tabular}

Source: 2020 primary data

Table 2.Shows the results Most of the respondents (73.3\%) have secondary education.

Table 3.Frequency distribution of respondents' knowledge about nutritional needs before being given health education at PMB Nanik Sidoarjo in 2020

\begin{tabular}{lcc}
\hline Knowledge & Frequency & Percentage $(\%)$ \\
\hline good & 5 & 16.7 \\
enough & 23 & 76.7 \\
less & 2 & 6.6 \\
\hline Total & 30 & 100
\end{tabular}

Source: 2020 primary data

Table 3. Shows the results Almost entirely (76.7\%) before getting education, the respondents 'knowledge about the nutritional needs of pregnant women is in the sufficient category

Table 4. Frequency Distribution of respondents' knowledge about nutritional needs before being given health education at PMB Nanik Sidoarjo 2020

\begin{tabular}{lcc}
\hline Knowledge & Frequency & Percentage (\%) \\
\hline Good & 28 & 93.3 \\
Enough & 2 & 6.7 \\
Less & 0 & 0 \\
\hline Total & 30 & 100 \\
\hline
\end{tabular}

Source: 2020 primary data

Table 4. It shows the results almost entirely (93.3\%) after getting education, the knowledge of respondents about the nutritional needs of pregnant women is in the good category 


\section{STRADA Jurnal Ilmiah Kesehatan}

DOI: $10.30994 /$ sjik.v9i2.506

ISSN: 2252-3847 (print); 2614-350X (online)

Vol.9 No.2 November 2020 Page. 1605-1610

Table 5. Wilcoxon Test

\begin{tabular}{|c|c|c|c|c|c|c|}
\hline & & $\mathrm{N}$ & Mean Rank & Sum of Ranks & Z hit & Sig. \\
\hline \multirow{4}{*}{$\begin{array}{l}\text { Pre-test } \\
\text { score-post- } \\
\text { test score }\end{array}$} & $\begin{array}{l}\text { Negative } \\
\text { ranks }\end{array}$ & $3^{a}$ & 15.5 & 465.00 & \multirow{4}{*}{$-4,965^{b}$} & \multirow{4}{*}{0,000} \\
\hline & $\begin{array}{l}\text { Positive } \\
\text { Ranks }\end{array}$ & $25^{\mathrm{b}}$ & \multirow[t]{2}{*}{15,5} & \multirow[t]{2}{*}{, 00} & & \\
\hline & Ties & $2^{c}$ & & & & \\
\hline & Total & 30 & & & & \\
\hline
\end{tabular}

Source: primary data, 2020

Table 6. Shows the results during the pre-test and post-test on the negative rank of 3 people before and after getting education, the knowledge of mothers decreased, in the positive rank As many as 25 people before and after receiving education, increased maternal knowledge and ties as many as 2 people before and after receiving education on maternal knowledge was the same. The test results using the Wilcoxon-test results obtained Z-value $-4,965$ and the significance of 0.000 ((p-value <0.05) means that there is an effect of using the emodemo method on the knowledge of pregnant women about the nutritional needs of pregnant women

\section{DISCUSSION}

In this study based on table 1 . It shows the results of most $(66.7 \%)$ respondents aged 20- 35 Age is a factor that can affect the development of a person's perceptive power and mindset, the older a person is, the better his mental development processes, but at a certain age, the increase in mental development processes is not as fast as when he was a teenager. a person can have an effect on the increase in knowledge he / she gets. (Notoadmojo, 2012) However, it does not rule out the possibility that someone's knowledge comes from previous knowledge, personal or other experiences and several other factors that can shape one's knowledge over a long period of time. and will last until it is over a old.

Table 2. Shows that the results of most $(73.3 \%)$ of the respondents' education are secondary education. The level of education determines whether it is easy for a person to absorb and understand the knowledge they get, in general, the higher a person's education the better the knowledge (Notoadmojo, 2012).

However, someone's knowledge is not absolutely obtained from formal education, but can be obtained from non-formal education. A person with a low level of education will not always have low knowledge, likewise someone with a high level of education will not always have good knowledge.

The pretest results showed that almost all respondents had sufficient knowledge, this happened because the respondents had already received material and counseling about the nutritional needs of pregnant women so that many answered correctly at the time of the pretest.

The results of the Wilcoxon Signed Ranks Test statistical test were obtained $\rho=0,00$ $\rho=0,00$ with $\alpha=0.05$ so $\rho \leq \alpha \rho \leq \alpha$ that HO was rejected, meaning that there was an effect of using the emodemo method on knowledge about the nutritional needs of pregnant women in PMB Nanik Sidoarjo

This is in line with previous studies where there was a change in knowledge about lactation management. before and after being given education using themethod Emo Demo 


\section{STRADA Jurnal Ilmiah Kesehatan}

DOI: $10.30994 /$ sjik.v9i2.506

ISSN: 2252-3847 (print); 2614-350X (online)

Vol.9 No.2 November 2020 Page. 1605-1610

with an averageincrease in knowledge of 5.2(Huriah, 2017). The same is the case with the results of research conducted by Dahlia, 2017 that there is a significant difference between the knowledge of students about the practice of washing hands with soap before and after providing health education with the Emo Demo method.

Health education activities using the Emo demo method in addition to providing health information can also upload the emotions of the subject so that the subject will be encouraged to make changes in behavior besides that the implementation of counseling is carried out simply using props so that the material provided is easier to accept and clear besides that too only takes a relatively short time, namely 15-20 minutes.

In health education, several emodemo modules are used, including IMAGING THE FUTURE, the module is delivered so that mothers know the importance of nutrition for the future of their children, besides using the ATIKA module (Ati, Eggs, Fish) sources of iron so that mothers know about the type of food needed during pregnancy (Fansi, 2018).

In the level of behavior change, attitude is thedomain secondafter knowledge. Knowledge is a factor that plays an important role in determining a person's attitude, with knowledge will form trust which further provides perspective on humans in preparing for reality and provides a basis for decision making and determining attitudes towards certain objects. Health education is part of the process to motivate targets in order to increase knowledge about health, so that they have better behavior and attitudes. (Notoatmodjo, 2012)

\section{CONCLUSION}

Emo demo is an effective way of health education in an effort to increase one's knowledge, according to the behavior center design theory that health education is intended not for thoughts but for feelings so that for this emodemo method what will experience a greater increase is attitude compared to knowledge therefore suggestions for further research to examine the effectiveness of using the emodemo method on attitudes.

\section{REFERENCES}

Arifin, Rochman. 2016. The Relationship between Mother's Level of Knowledge About Nutritional Needs of Pregnant Women and Nutritional Status of Pregnant Women at Pleret Health Center, Bantul. Scientific Writing. Study Program of Nursing, Muhammadiyah University of Yogyakarta.

Dahlia Indah Amareta \& Efri Tri Ardianto. Health Counseling with the Emo-Demo Method Effectively Improves the Practice of CTPS at MI Al-Badri Kalisat, Jember Regency. National Seminar on Research Results. Jember State Polytechnic; ISBN: 978-60214917-5-1

Fansi Perdana Putri. (2018) Teach Candidates for trainer 12 emodemo modules. http://dinkes.surabaya.go.id/portal/bberita/ Teach -calon-trainer-12-modul-emo-demo /.

GAIN. 2013. Inspiring Indonesian mothers to change their eating and feeding practices. Global Alliance for Improved Nutrition. Accessed on June 2, 2020 from https://www.gainhealth.org/programs/

Huriah N. (2017) Increasing Knowledge of Posyandu Cadres in Lactation Management through Lecture Method in Rangkap Jaya Village, Pancoran Mas District, Depok City. ARKESMAS Journal. 2 (1): 1-6

Indonesian Ministry of Health. 2018. Basic Health Research. Jakarta: Ministry of Health RI. Accessed on 24 June 2020 from http://www.depkes.go.id/resources/download/infoterkini/materi_rakorpop_2018/Hasi 


\section{STRADA Jurnal Ilmiah Kesehatan}

DOI: $10.30994 /$ sjik.v9i2.506

ISSN: 2252-3847 (print); 2614-350X (online)

Vol.9 No.2 November 2020 Page. 1605-1610

1\%20Riskesdas\%202018.pdf

Notoaatmodjo, S. (2012). Health Behavior and Education. Jakarta: RinekaCipta.

Supariasa \& Hardinsyah. 2017. Nutrition Science: Theory and Application. Jakarta: EGC

Setiawati, S. (2011). Learning Process in Health Education. (Agung, Ed.). Jakarta: First Trans Info 